\title{
PENGEMBANGAN BAHAN AJAR PEMBELAJARAN MEMBACA PEMAHAMAN LITERAL BERBASIS LITERASI KITAB KUNING MAHASISWA PROGRAM STUDI PBSI STKIP NURUL HUDA SUKARAJA
}

\author{
Suryani ${ }^{1}$, Hastuti Retno Kuspiyah ${ }^{2}$, Lailatul Fitriyah ${ }^{3}$ \\ STKIP Nurul Huda Sukaraja, Palembang, Indonesia ${ }^{1,2,3}$ \\ suryani@stkipnurulhuda.ac.id ${ }^{1}$, retno@stkipnurulhuda.ac.id ${ }^{2}$, lailatul@stkipnurulhuda.ac.id ${ }^{3}$
}

\begin{abstract}
To follow up on previous research and improve reading comprehension by developing literacybased teaching materials for the yellow book were the reason for conducting this research. The research objective was to produce teaching materials learning products in the form of student worksheets for literal reading comprehension based on yellow book literacy in the PBSI STKIP Nurul Huda Sukaraja study program. This research was a kind of development research. The method used was the model development method. The population was all students of the PBSI study program first semester, with 15 students as a sample. The approach used was a mixedmethod-data collection techniques in observation, interviews, questionnaires, and tests. The analysis technique that used was qualitative and quantitative data. The analysis findings showed that the teaching materials were in the form of student worksheets, which have special characters proven to help students learn literal reading comprehension material. Furthermore, based on quantitative analysis, it was found that the t-test of sig. $(2$ tailed $)=0.043 \leq 0.05$.
\end{abstract}

Keywords: worksheet, literation, reading comprehension

\section{ABSTRAK}

Penelitian ini didasari oleh dua hal yakni sebagai bentuk tindak lanjut dari penelitian sebelumnya dan sebagai upaya untuk meningkatkan hasil belajar membaca pemahaman melalui pengembangan bahan ajar berbasis literasi kitab kuning. Tujuan penelitian adalah menghasilkan produk pembelajaran materi ajar berupa Lembar Kerja Mahasiswa pemahaman membaca literal berbasis literasi kitab kuning pada program studi PBSI STKIP Nurul Huda Sukaraja. Penelitian ini adalah penelitian pengembangan. Metode yang digunakan adalah metode pengembangan model (research development). Populasi nya adalah seluruh mahasiswa program studi PBSI semester I dengan jumlah mahasiswa sebanyak 15 sebagai sampel. Pendekatan yang digunakan adalah pendekatan campuran (mix method). Teknik pengumpulan data berupa observasi, wawancara, angket, dan tes. Teknik analisis menggunakan kualitatif dan kuantitafi data. Hasil temuan analisis menujukan bahwa bahan ajar bentuk Lembar Kerja Mahasiswa (LKM) yang memiliki karakter khusus dimana terbukti dapat membantu mahasiswa dalam mempelajari materi membaca pemahaman literal. Lebih jauh lagi berdasarkan analisis kuantitatif diperoleh bahwa $\mathrm{t}_{\text {-test }}$ dari sig. $(2$ tailed $)=0,043 \leq 0,05$.

Kata Kunci: bahan ajar, literasi, membaca pemahaman

\section{PENDAHULUAN}

Pengembangan Bahan Ajar Pembelajaran Membaca Pemahaman Literal Berbasis Literasi Kitab Kuning Mahasiswa Program Studi PBSI STKIP Nurul Huda Sukaraja 
Membaca adalah satu dari empat keterampilan berbahasa yang harus dimiliki oleh setiap orang. Kenyataan bahwa membaca merpakan jendela dunia tidak dapat diabaikan. Di samping itu, beberapa ulasan di media menunjukkan bahwa kebiasaan membaca membawa dampak yang postitif bagi pelakunya, baik secara kesehatan fisik maupun psikologis.

Setiap pembelajar wajib memiliki keterampilan membaca, terutama mahasiswa. Farr (Dalman, 2013) mengemukakan bahwa "reading is the heart of education", membaca adalah jantung pendidikan. Selain itu, hampir keseluruhan proses pembelajaran/kegiatan akademik tidak bisa lepas dari membaca.

Membaca dapat dipahami sebagai suatu langkah pemecahan sandi (decoding) terhadap simbol-simbol tertulis karena diawali dengan memahami segmensegmen terkecil (huruf, suku kata, kata) kemudian mencakup unit-unit yang lebih besar (anak kalimat, kalimat, paragraf) (Ghazali, 2010). Menurut Tarigan, membaca adalah proses yang dilaksanakan dan dipakai oleh pembaca untuk mendapatkan informasi yang disampaikan oleh penulis melalui media tulis berupa kata atau kalimat (Dalman, 2013). Menurut Douglas membaca merupakan proses pembentukan makna segala sesuatu yang terdapat di suatu lingkungan tempat pembaca mengembangkan kesadaran (M, 2013).

Untuk memperoleh kemampuan membaca, seseorang perlu melalui proses pembelajaran. Dalam hal ini adalah pembelajaran membaca. Pembelajaran membaca dapat diartikan sebagai rangkaian kegiatan yang dilakukan siswa untuk mencapai keterampilan membaca. Pembelajaran membaca dilakukan tidak hanya supaya siswa dapat membaca, melainkan merupakan suatu proses yang melibatkan seluruh kegiatan mental dan kemampuan nalar dalam memahami, mengkritisi, dan menghasilkan sebuah wacana tertulis. Karenanya, tujuan pembelajaran membaca bukan sekedar mengeja huruf, kata per kata, tetapi memperoleh makna dari apa yang tertulis dalam teks. Dalam hal ini, Abidin menjelaskan, paling tidak terdapat tiga tujuan utama pembelajaran membaca, yaitu 1) memungkinkan siswa menikmati kegiatan membaca, 2) mampu membaca dalam hati dengan kecepatan membaca yang fleksibel, dan 3) memperoleh tingkat pemahaman yang cukup atas isi bacaan(Abidin, 2012).

Berdasarkan hasil wawancara dengan dosen pengampu mata kuliah keterampilan membaca pada Prodi PBSI STKIP Nurul Huda, ditemukan beberapa permasalahan dalam pembelajaran membaca, terutama berkaitan dengan membaca pemahaman. Diantara persoalan itu adalah berkaitan dengan bahan ajar yang digunakan yang kurang mengakomodir kebutuhan dalam pembelajaran membaca pemahaman. Selain itu, hasil tes kemampuan membaca pemahaman yang dilakukan pada 15 Oktober 2019 menunjukkan bahwa kecepatan membaca mahasiswa adalah $256,11 \mathrm{kpm}$ dengan pemahaman isi yang cukup, yaitu $42 \%$.

Penelitian ini mencoba untuk menemukan solusi terkait dengan persoalan diatas. Selain itu penelitian ini merupakan tindak lanjut dari peneltian sebelumnya dan merupakan respon dari hasil pra penelitian yang menunjukkan perlunya upaya untuk meningkatkan hasil belajar membaca pemahaman melalui pengembangan bahan ajar berbasis literasi kitab kuning (Likiku). Penelitian ini fokus 
pada pengembangan bahan ajar untuk

materi mebaca pemahaman berbasis pembelajaran Likiku.

Yang dimaksud dengan bahan ajar adalah segala bentuk alat yang dipaki oleh guru pada saat pembelajaran. Bahan ajar membantu siswa untuk lebih memahami kompetensi yang harus dimiliki secara berurutan. Dengan harapan penguasaan tehadap kompetensi tersebut tercapai secara utuh dan terpadu (Majid, 2013).Tidak berbeda jauh dengan pendapat Majid, Suyitno menjelaskan bahwa bahan ajar berkaitan dengan materi yang disusun dengan berurutan, bisa berbentuk bahan ajar tertulis atau tidak tertulis. Bahan ajar tersebut meungkinkan terciptanya kondisi belajar yang kondusif. (Kristian \& Nova Kristian, Suyono, 2016).

Diantara beberapa fungsi bahan ajar adalah: 1) Menghemat waktu dalam proses pembelajaran, 2) Merubah peran pendidik menjadi fasilitator, 3) Meningkatkan kualitas pembelajaran, 4) Menjadi pedoman pendidik dalam pembelajaran(Mukhlis \& Asnawi, 2019).

Depdiknas mengklasifikasikan materi ajar menjadi lima, yakni fakta, konsep, prinsip, prosedur, dan sikap. Fakta adalah hal-hal yang berwujud kenyataan dan kebenaran, mencakup nama objek, peristiwa sejarah, dan lain-lain. Konsep memiliki pengertian sebagai segala pengertian baru yang muncul sebagai hasil pemahaman, meliputi; pengertian, ciri khusus, karakteristik dan sebagainya. Prinsip adalah hal-hal utama, serta mempunyai kedudukan penting, mencakup; detail, rumus, dan lain-lain. Prosedur merupakan tindakan sistematis dalam mengerjakan suatu kegiatan. Sikap adalah hasil belajar aspek prilaku, misalnya nilai kejujuran, semangat, dan lain-lain (Arsanti, 2018).
Pengelompokan bahan ajar dapat meliputi; bahan ajar tertulis, pandang dengar, elektronik, dan interaktif terintegrasi atau disebut dengan mediamix. Suatu bahan ajar, minimal berisi; petunjuk belajar (siswa/guru), kemampuan yang akan diperoleh, informasi pendukung, beberapa latihan, petunjuk kerja (dapat berupa lembar kerja/LK) dan penilaian(Majid, 2013).

Untuk dapat dikatakan baik, bahan ajar harus memenuhi karakteristik bahan ajar yang baik. Bahan ajar yang berbentuk buku pelajaran seharusnya memenuhi empat kriteria antara lain: 1) materi sesuai dengan kurikulum, 2) memenuhi prinsip belajar, 3) bahasa dan tingkat keterbacaan baik, dan 4) desain buku atau grafika menarik (M, 2013).

Berkaitan dengan pembelajaran membaca, di tingkat perguruan tinggi, tujuan mata kuliah keterampilan membaca tidak hanya membekali mahasiswa dengan kemampuan membaca yang baik, tetapi juga membekali mahasiswa dengan pengetahuan terkait membaca. Seperti bagaimana mengukur kemampuan membaca, tahapan membaca, dan beberapa teknik membaca.

Menurut Gillet membaca pemahaman melibatkan pengetahuan latar, struktur teks, dan pencarian informasi secara aktif. Senada dengan pendapat tersebut, Golinkoff menyatakan tiga komponen pokok membaca pemahaman, yaitu 1) menguraikan, 2) akses leksikal, dan 3) organisasi bacaan, yaitu usaha mendapatkan makna yang lebih besar dari unit yang kecil (M, 2013).

Dalman menjelaskan bahwa membaca pemahaman dikelompokan menjadi empat tingkatan, yaitu 1) pemahaman literal, 2) pemahaman interpretatif, 3) pemahaman kritis, dan 4) 
pemahaman kreatif (Dalman,

2013).Hampir sama dengan yang

disampaikan Rubin, menurut Burns ada dua jenis pemahaman membaca, yakni pemahaman literal dan pemahaman tingkat tinggi. Masih menurut Burns, pemahaman tingkat tinggi meliputi tiga tingkatan, yaitu pemahaman interpretatif, kritis, dan kreatif (M, 2013).

Yang dimaksud pemahaman literal adalah pembaca hanya memahami makna yang tersurat, sebagimana teks yang ada. Menurut Imam Syafi'i, membaca pemahaman literal meliputi pemahaman arti kata, kalimat, serta paragraf dalam teks. Karenanya, untuk pengukuran membaca jenis ini, dapat digunakan katakata Tanya 5W 1H (What, Who, Where, When, Why, dan How) (Dalman, 2013).

Literasi pada dasarnya merujuk pada kemampuan membaca dan kemampuan menulis yang melibatkan kemampuan berbicara. Oleh karena itu, literasi identik dengan empat kemampuan berbahasa. Seseorang bisa disebut literate (terdidik) jika menguasai empat keterampilan berbahasa secara bersamaan(Somadyo, 2011).

Sementara itu, kitab kuning mengacu pada kitab-kitab lama yang bermuatan materi pembelajarn agama Islam. Materi ini menjadi materi pokok pembelajaran pokok di pesantren, yang meliputi dari fiqih, aqidah, akhlaq/tasawuf, nahwu dan ilmu sharf, hadits, tafsir, dan ilmu-ilmu al-qur'aan. Termasuk materi pembelajaran di pesantren adalah ilmuilmu social. Istilah lain dari kitab kuning adalah kitab gundul karena memang tidak memiliki harakat (Fitriyah et al., 2019).

Proses pembelajaran kitab kuning meliputi empat tahapan yakni utawi iki $\mathrm{iku}$, sorogan, bandongan, dan diskusi. Keempat tahapan ini memiliki kesamaan pola dengan tahapan membaca pemahaman dimana keduanya mencangkup keterampilan membaca dan ketarampilan menulis sehingga pada penelitian sebulmnya persamaan ini melahirkan pemahaman mengenai pengertian pembelajaran literasi kitab kuning.

Pembelajaran literasi kitab kuning adalah pembelajaran yang menekankan pada aspek kemampuan membaca dan menulis yang diterapkan oleh pesantren dalam mengkaji kitab kuning. Yang dikembangkan dengan menggunakan metode utawi iki iku, sorogan, bandongan, dan diskusi (Fitriyah et al., 2019).

\section{METODOLOGI PENELITIAN}

Penelitian ini merupakan penelitian pengembangan (research development) yang bermaksud mengembangkan produk pembelajaran berbentuk bahan ajar. Hasil dari penelitian adalah produk pembelajaran materi ajar berupa Lembar Kerja Mahasiswa pemahaman membaca literal berbasis literasi kitab kuning. Pendekatan yang digunakan adalah pendekatan campuran (mix method) yaitu gabungan antara pendekatan kualitatif dan kuantitatif dengan memasukkan data kuantitatif dan data kualitatif dalam satu penelitian (Abidin, 2012).

Mengadaptasi teori tahapan penelitian teori Borg dan Gall yang terdiri dari 10 tahap. Teori tersebut kemudian dirangkum menjadi enam tahapan pokok. Keenam tahapan tersebut adalah: (1) tahap studi pendahuluan, (2) tahap studi pengembangan, (3) uji ahli, (4) tahap revisi awal, (5) tahap uji lapangan dan (5) tahap revisi akhir. Prosedur tahapan pengembangan hanya sampai tahap develop (pengembangan). Pengumpulan 
data dilakukan dengan teknik: observasi, wawancara, angket, dan tes.

Analisis data yang digunakan bersifat kualitatif dan kuantitatif. Data kualitatif dianalisis dengan tahapan sebagai berikut yaitu membaca dan menulis, mendeskripsikan dan mengklasifikasikan data tersebut. Sementar itu data yang dianalisis secara kuantitatif ialah skor hasil tes kemampuan membaca literal mahasiswa yaitu pre-test dan posttest. Data ini dianalisis untuk uji keefektifan dan kelayakan produk dengan menggunakanuji-t.

\section{HASIL DAN PEMBAHASAN}

Penelitian ini dilakukan di STKIP Nurul Huda Sukaraja Prodi PBSI, pada mata kuliah Keterampilan Membaca dengan materi Membaca Pemahaman Literal. Pada tahap pendahuluan telah dilakukan bebrapa tahapan yakni observasi, wawancara, tes, dan angket yang kemudian menghasilkan analisis kebutuhan berupa diperlukannya pengembangan bahan ajar untuk materi membaca pemahaman literal (MPL) berbasis pembelajaran literasi kitab kuning (Likikun).

Hal tersebut didasari oleh ditemukannya kesulitan mahasiswa dalam mempelajari materi MPL khususnya dalam menentukan struktur wacana, jenis pargraf/menemukan ide pokok, menemukan makna kata sukar dalam kalimat, mengidentifikasi informasi, dan membuat ringkasan. Selain itu harapan mahasiswa tentang suatu proses pembelajaran yang mengedepankan keaktifan mahasiswa serta mempermudah mereka memahami materi secara keseluruhan selaras dengan hasil penelitian terdahulu yang menyatakan kesesuaian pembelajaran Likiku untuk diterapkan dalam proses KBM materi MPL. $\begin{array}{ccr}\text { Oleh karena ini } & \text { penelitian } \\ \text { pengembangan } & \text { dilakukan } & \text { dengan }\end{array}$

merancang desain bahan ajar Lembar Kerja Mahasiswa (LKM) yang dirancang khusus dengan mengaplikasikan pembelajaran Likiku. Dalam prosesnya pembelajaran Likiku mengalami beberapa modifikasi seperti; lalaran yang biasanya berupa lagu/memiliki nada berubah menjadi hafalan materi pokok tanpa nada, Likiku di pondok pesantren dilakukan secara individual sedangkan dalam penerapannya pada pembelajaran materi umum pembelajaran Likiku dimodifikasi menjadi pembelajaran dengan bentuk kelompok kecil.

Berdasarkan proses Pendahuluan dan Metodologi penelitian dilaksanakanlah proses penelitian pengembangaan bahan ajar berupa LKM. Bahan ajar bentuk LKM dipilih menyesuaikan waktuk belajar di perkuliahan yang jauh lebih sempit dibandingkan dengan waktu belajar di pondok pensantren.

Tahapan pelaksanaan penelitian diawali dengan desain produk, uji coba terbatas, validasi dan evaluasi, penyusunan hasil penelitian. Setelah LKM selesai didesain, LKM diujikan secara terbatas kepada perseorangan dan kepada sekelompok kecil mahasiswa. Hasilnya menjadi bahan untuk divalidasi dan dievaluasi. Pada proses ini didapatkan hasil yang menyatakan LKM masih sulit dipahami karena materi masih terlalu luas, bahasa yang terlalu kaku, dan langkahlangkah pembelajaran masih sukar dipahami.

Berdasarkan hasil tersebut peneliti melakukan refisi draf I dengan melakukan beberapa perbaikan berdasarkan hasil validasi dan evaluasi sebelumnya. Perbaikan berupa materi yang lebih ringkas dengan dibentuk menjadi per poin, menyediakan petunjuk penggunaan bagi dosen dan petunjuk penggunaan bagi mahasiswa sebagai panduan untuk menggunakan LKM secara praktis. 
Hasil refisi draf satu selesai dilanjutkan dengan uji coba 1 dimana keseluruhan mahasiswa telah diberikan perlakuan pembelajar MPL dengan menggunakan bahan ajar LKM. Hasil uji coba 1 menyatakan bahwa LKM sudah lebih baik dan dapat digunakan secara mudah oleh mahasiswa hanya saja masih diperlukan revisi dibeberapa bagian seperti desain layout harus dibuat lebih menarik, jarak antar baris pada wacana yang dijadikan bahan latihan harus dibuat lebih lebar agar mahasiswa lebih leluasa saat melakukan proses maknani dan kodefikasi. Berdasarkan hasil tersebut dilakukanlah refisi draf dua.

Setelah refisi draf dua dilakukan kembali uji coba berupa uji coba secara luas dengan melibatkan semua mahasiswa yang menjadi target pembelajaran. Pada tahap ini hasil uji coba diambil sebagai data kualitatif sekaligus data kuantitatif. Nilai-nilai yang diperoleh diolah dengan SPSS 16.

Berdasarkan keseluruahan proses pelaksanaan penelitian ditemukan tiga pokok hasil besar yang diperoleh sebagai berikut:

1. Telah dihasilkan sebuah produk bahan ajar cetak LKM (Lembar Kerja Mahasiswa).

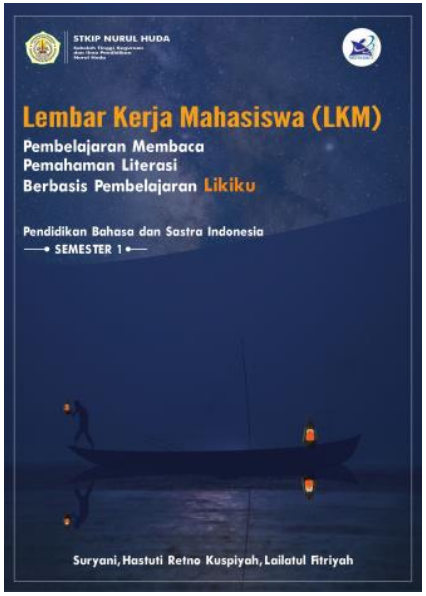

Gambar 1. Gambar Sampul Depan

2. Bahan ajar berupa LKM ini memiliki karakteristik khusus yang penggunaannya dirancang dan disesuaikan dengan langkah-langkah pembelajaran Likiku, sehingga lembarlembar proses latihannya disesuaikan dengan aturan yang berlaku pada pembelajaran Likiku.

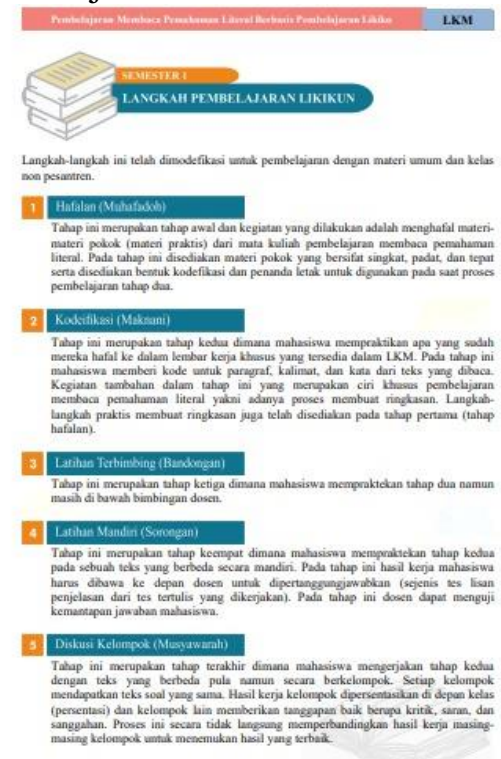

Gambar 2. Langkah Pembelajaran Likiku

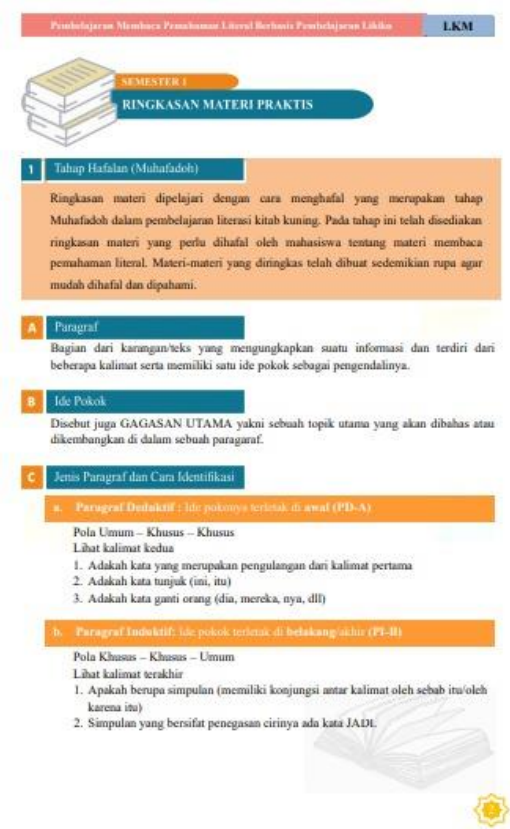

Gambar 2. Ringkasan Materi Praktis

Pengembangan Bahan Ajar Pembelajaran Membaca Pemahaman Literal Berbasis Literasi Kitab Kuning Mahasiswa Program Studi PBSI STKIP Nurul Huda Sukaraja 


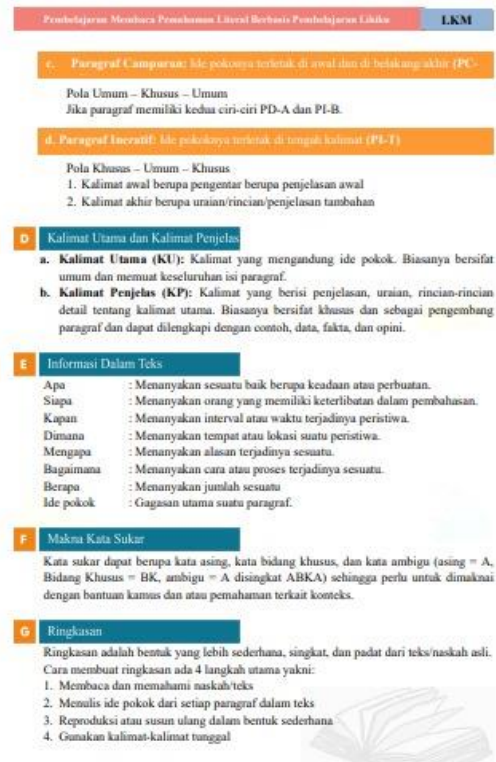

Gambar 4. Lanjutan Ringkasan Materi Praktis
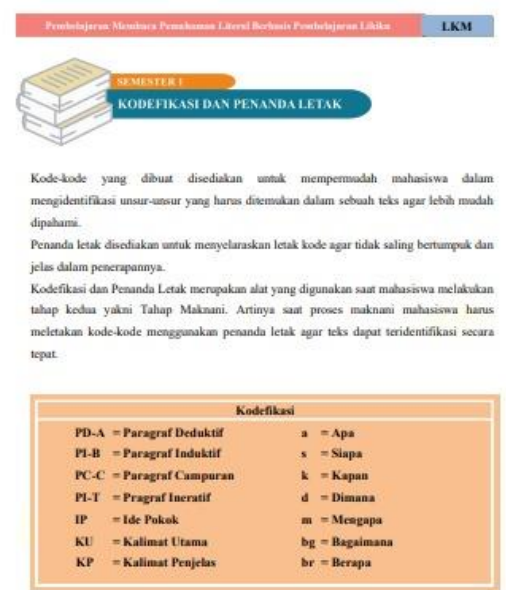

Gambar 5. Kodefikasi dan Penanda Letak
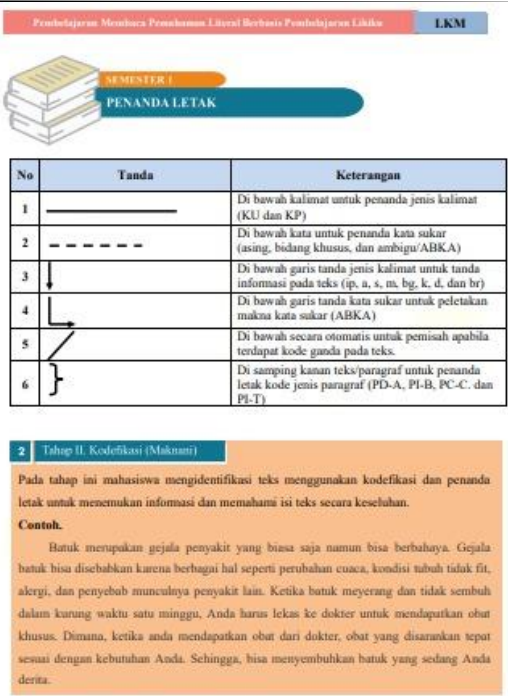

Gambar 6. Penanda Letak

Gabar-gambar dari bagian isi LKM yang menjadi ciri karakteristik LKM.

3. LKM ini berhasil membantu siswa lebih mudah dalam memahami materi pembelajaran membaca pemahaman literal dilihat dari hasil tes yang menunjukan adanya peningkatan sebagaimana data analisis menggunakan uji t $(0,043 \leq 0,05)$. Data statistik dapat dilihat pada Tabel berikut:

Table 1

Paired Sample t-test

\begin{tabular}{|c|c|c|c|c|c|c|c|c|c|}
\hline \multicolumn{10}{|c|}{ Paired Samples Test } \\
\hline & & \multicolumn{5}{|c|}{ Paired Differences } & \multirow[b]{3}{*}{$t$} & \multirow[b]{3}{*}{ df } & \multirow{3}{*}{$\begin{array}{l}\text { Sig. (2- } \\
\text { tailed) }\end{array}$} \\
\hline & & \multirow[b]{2}{*}{ Mean } & \multirow{2}{*}{$\begin{array}{c}\text { Std. } \\
\text { Deviatio } \\
\mathrm{n}\end{array}$} & \multirow{2}{*}{$\begin{array}{l}\text { Std. } \\
\text { Error } \\
\text { Mean }\end{array}$} & \multicolumn{2}{|c|}{$\begin{array}{l}95 \% \text { Confidence } \\
\text { Interval of the } \\
\text { Difference }\end{array}$} & & & \\
\hline & & & & & Lower & Upper & & & \\
\hline Pair 1 & $\begin{array}{l}\text { Pretest } \\
\text { Posttest }\end{array}$ & -11.188 & 20.266 & 5.066 & $-21.986 \mid$ & -.389 & -2.208 & 15 & .043 \\
\hline
\end{tabular}

\section{SIMPULAN}

Penelitian ini berhasil mengembangkan sebuah bahan ajar pada materi membaca pemahaman literal.

Bahan ajar pemebelajaran membaca pemahaman literasi berbasis pembelajaran Likiku di Prodi PBSI STKIP Nurul Huda

Pengembangan Bahan Ajar Pembelajaran Membaca Pemahaman Literal Berbasis Literasi Kitab Kuning Mahasiswa Program Studi PBSI STKIP Nurul Huda Sukaraja 
Sukaraja dapat dibuat dalam bentuk LKM dengan pertimbangan.

1. Bahan ajar bentuk LKM dipilih karena penelitian merujuk pada satu materi bukan satu mata kuliah yakni membaca pemahaman literal.

2. Bentuk LKM lebih dapat menyesuaikan dengan dengan langkah-langkah pembelajaran Likiku.

Pembelajaran Likiku dapat membantu mahasiswa dalam mempelajari materi pembelajaran membaca pemahaman literal. Hal ini terlihat dari adanya perbedaan nilai signifikan mahasiswa dari perbandingan hasil nilai pada studi pendahualan dan nilai hasil tes akhir secara luas. Berdasarkan hasil analisis data menggunakan SPSS 16 diperoleh bahwa nilai sig. ( 2 tailed) adalah sebesar $0,043 \leq 0,05$.

Dalam proses ini pembelajaran Likiku mengalami beberapa modifikasi yakni pada penyampaian materi pokok hafalan, dan sorogan yang biasanya dilakukan individual dimodifikasi menjadi kelompok kecil.

\section{REFERENSI}

Abidin, Y. (2012). Keterampilan Membaca. PT Rafika Aditama.

Arsanti, M. (2018). Pengembangan Bahan Ajar Mata Kuliah Penulisan Kreatif Bermuatan Nilai-Nilai Pendidikan Karakter Religius Bagi Mahasiswa Prodi Pbsi, Fkip, Unissula. KREDO: Jurnal Ilmiah Bahasa Dan Sastra, 1(2), 71-90. https://doi.org/10.24176/kredo.v1i2.2107

Dalman. (2013). Keterampilan Membaca. PT Rajagrafindo Persada.

Fitriyah, L., Marlina, M., \& Suryani, S. (2019). Pendidikan Literasi pada Pembelajaran Kitab Kuning di Pondok Pesantren Nurul Huda Sukaraja. Titian Ilmu: Jurnal Ilmiah Multi Sciences, 11(1), 20-30. https://doi.org/10.30599/jti.v11i1.351

Ghazali, A. S. (2010). Pembelajaran Keterampilan Berbahasa: Dengan
Pendekatan Komunikatif-Interaktif. PT Rafika Aditama.

Kristian, N., \& Nova Kristian, Suyono, S. (2016). Pengembangan Bahan Ajar Menulis Laporan Skemata Bacaan. Jurnal Pendidikan, Vol. 1, No. 2, 1(1), 203-213.

M, S. F. (2013). Kemampuan membaca pemahaman literal dan interpretatif melalui pendekatan konstruktivisme. 6(2).

Majid, A. (2013). Perencanaan Pembelajaran: Mengembangkan Standar Kompetensi Guru. PT Remaja Rosdakarya.

Mukhlis, M., \& Asnawi, A. (2019). Teks Anekdot dalam Cerita Lisan Yong Dollah Pewarisan Orang Melayu Sebagai Alternatif Pemilihan Bahan Ajar Bahasa Indonesia. Geram, 7(2), 30-43. https://doi.org/10.25299/geram.2019.vol7 (2). 3774

Somadyo, S. (2011). Strategi dan Teknik Pembelajaran Membaca. Graha Ilmu.

Pengembangan Bahan Ajar Pembelajaran Membaca Pemahaman Literal Berbasis Literasi Kitab Kuning Mahasiswa Program Studi PBSI STKIP Nurul Huda Sukaraja 